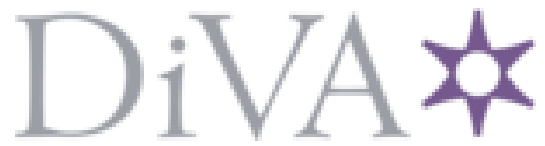

http://www.diva-portal.org

Preprint

This is the submitted version of a chapter published in Borders in Mathematics Pre-Service Teacher Education.

Citation for the original published chapter:

Bagger, A., Roos, H. (2020)

The Shared Duty of Special Educational Support in Mathematics: Borders and Spaces in Degree Ordinances for Pre-service Teachers

In: Limin Jao; Nenad Radakovic (ed.), Borders in Mathematics Pre-Service Teacher Education (pp. 141-161). Springer

https://doi.org/10.1007/978-3-030-44292-7_7

N.B. When citing this work, cite the original published chapter.

Permanent link to this version:

http://urn.kb.se/resolve?urn=urn:nbn:se:oru:diva-83740 
Bagger, A. \& Roos, H. (in press). The shared duty of special educational support in mathematics: borders and spaces in degree ordinances for pre-service teachers. In N. Radakovic \& L Jao (Eds.), Borders in Mathematics Pre-Service Teacher Education. Springer. Authors copy.

\section{The shared duty of special educational support in mathematics: borders and spaces in degree ordinances for pre-service teachers}

Anette Bagger, Örebro University Sweden, Fakultetsgatan 1, 70182 Örebro anette.bagger@oru.se

Helena Roos, Linnaeus University Sweden, Universitetsplatsen 1

35195 Växjö

helena.roos@lnu.se

This chapter investigates the future shared duties of special education pre-service teachers in mathematics and mathematics pre-service teachers for primary school to support students in need of support in mathematics. Within the Swedish context, teacher education training policy frames special education teachers in mathematics (STms) as the historians of schooling, in that they carry specific knowledge about how students in need of support have been treated earlier, and recognise that current practices and policies have been motivated by the history and culture of Swedish schools. This framing also suggests that they have the expertice in supporting students in need of special support and an understanding of specific disabilities or prerequisites for learning that these students can have. In contrast, mathematics teachers for primary school (MTPs) are framed as: being responsible for the overall education taking place in classrooms, being willing to collaborate and learn from other professions involved in the students learning and development, and needing to pay attention to those other professions' experiences and knowledge. In addition, the teacher education training policy indicates that MTPs are supposed to cooperate, listen, and reflect, whereas STms are to lead, be independent, analyse, and drive school development. Furthermore, the position, role, and authority of STms are not supported by the Swedish Education Act. This together with the sometimes contradictory roles identified by each of the profession's goals in their degree ordinance could put MTPs' and STms' shared duties at risk, and creates a need for negotiation. A possible way forward, in order to counteract this risk, might be shared courses during teacher training. This could presumably prepare for future negotiations and collaborations of roles and responsibilities.

Keywords: Special educational support, mathematics teachers, pre-service teacher training, special education teachers in mathematics.

\section{Introduction}

Special education support in mathematics is a duty shared between different professionals, such as psychologists, special education teachers, mathematics teachers, and teaching assistants (see for example Radford, Bosanquet, Webster \& Blatchford, 2015) each of whom take responsibility for different areas. Therefore, the duties demand collaboration and coordination of different expertise, training, and competencies (Sherer, Beswick, DeBlois, Healey \& Opitz, 2016; Roos \& Gadler, 2018; Secher Schmidt, 2016). The method usually used by special education teachers in order to support students, is individualized or small-group teaching and supervising the classroom mathematics teachers. Special education teachers often have a relational perspective on difficulties and an equity discourse on education (Göransson, Lindqvist, \& Nilholm, 2015). 
Bagger, A. \& Roos, H. (in press). The shared duty of special educational support in mathematics: borders and spaces in degree ordinances for pre-service teachers. In N. Radakovic \& L Jao (Eds.), Borders in Mathematics Pre-Service Teacher Education. Springer. Authors copy.

When it comes to students who face challenges learning mathematics, their achievement can be connected to teachers' skills, and in these cases, research shows that there is a need for teacher professional development (Griffin, Pape, Algina, Bae, Prosser, \& League, 2018). Furthermore, students' mathematical development is impacted by teachers' professional understanding and knowledge about how to support such struggling students (Bottge, Rueda, Serlin, Hung \& Kwon, 2007; Gal \& Linchevski, 2010; Hinton, Flores, Burton, \& Curtis, 2015; Moscardini, 2010; Moscardini, 2017). Professional skills, knowledge and understanding will play out in the classroom through mathematics and special education teachers' shared assignment to support students. For example, when they prioritize what is important to do to support students, these teachers should consider who should be involved in the students' education and why. It is also important for the teachers to analyse and evaluate the design of their teaching approaches and the assignments given to students, in order to understand the suitability for different students. We claim that the spaces and borders for the shared assignment begin to form during pre-service teacher training. In the long run, how the priorities are made determines if and how the school provides and develops efficient and appropriate education for every student in mathematics at the local and national levels. Some of these students are considered to be students in need of support in mathematics. There is no consensus on the concept of "students in need" (Heyd-Metzuyanim, 2013). For this chapter, we understand students in need of support in mathematics as not always being about achievement or disabilities, instead it is a need emerging in relation to the context and system of education in mathematics. We thereby agree with Méndez et al. (2008) who state: "Disability is regarded as being located in particular types of activity systems and learning cultures rather than within an individual" (p. 63). We also assert that different education professionals are affected by the structure, routines and culture of the educational system in the classroom and of the school. These systems and cultures will have an impact on how and when students experience various aspects of teaching as hindering their learning. The needs are thereby closely connected to situated social aspects of teaching and learning: "We have adopted the concept the student in need of special education in mathematics in order to emphasise the social aspect. The word "in" is here of great importance. The student is in need, not with needs" (Bagger \& Roos, 2015, p.34).

At the same time, there seems to be a lack of evaluation of and research on how preservice teacher training contributes to learning regarding these factors in the educational goals stated in the degree ordinance, at least in the Swedish context. A search was conducted for peerreviewed journal articles during the last ten years on the ERIC database using the keywords "teacher education", "special education", "mathematic*", and "goal*", and only 11 hits were found. After reading the abstracts, several were found to focus on the role of special education teachers, how to teach mathematical content to students in need of support, or collaboration between types of teachers. While articles focused on in-service teachers and their work, few focused on pre-service teacher training. For the few concerned with pre-service teacher training, none of them focused on the goals of the teacher training programs for mathematics or special education students.

Cultural boundaries influence how teacher education prepares teachers on how to educate students in need of support as well as how to collaborate with other professionals to support these students. For example, the knowledge of mathematics teachers has been shown to reflect current national debates in some countries. More specifically, Blömeke, Suhl, and 
Bagger, A. \& Roos, H. (in press). The shared duty of special educational support in mathematics: borders and spaces in degree ordinances for pre-service teachers. In N. Radakovic \& L Jao (Eds.), Borders in Mathematics Pre-Service Teacher Education. Springer. Authors copy.

Döhrmann (2013) describe how this occurred in Taiwan, Singapore, Russia, Poland, USA and Norway, and state that "the knowledge profiles of the future teachers matched the respective national debates. This result points to the influences of the cultural context on mathematics teacher knowledge" (p. 795). National and cultural boundaries need to be acknowledged, explored, and placed in an international context in order to be better understood, as well as to create a high-quality foundation for developing and guiding teacher education (Blömeke, Hsieh, \& Schmidt 2013). This chapter contributes to exploring national and cultural boundaries through the case of Sweden by analyzing goals in teacher exams as they are stated in the higher education ordinance. The goals are understood as governing pre-service teachers' opportunities to learn (OTL). OTL as concept has been used in research for approximately half a century and focuses on the goals of education, what is afforded to learn and how these affordances depend on, among other things, curricula, culture, and programs in education (Wang \& Tang, 2013). OTL also goes beyond directions and implementations of curricula and refers to socio-political aspects of who the learner is and for whom education functions which in turn derives from the context and system at hand and is connected to issues of equity to learn and reach targets (Lester, 2007).

Thus in this chapter, OTL refers to what is offered through the educational goals in regard to what can be learned and how this affects collaboration between the professions. OTL will affect how pre-service teachers (both mathematics and special education) develop the knowledge needed in their future profession, and for their joint assignment to support students in need of support in the subject of mathematics. The exploration of country-specific borders of the preservice teachers OTL, may serve as a foundation to explore and reflect on other national settings and borders.

\subsection{Special education in mathematics}

Learning in STEM (science, technology, engineering, and mathematics) is often debated and a focus within school systems, and sometimes, mathematics is considered to be the core of these subjects. The development of mathematics has often been stressed as urgent in order to protect democracy and success for both individuals and countries (Erdogan, Niyazi, \& Stuessy, 2016; Grek, 2009). Professional development in the form of in-service training in specific subjects is often implemented to raise standards and goal achievement among students, as well as students' OTL in these subjects (for example, see Piasta, Logan, Pelatti, Capps, \& Petrelli, 2015). OTL has also been a focus of research in order to "interpret cross-national patterns of math achievement" (Bachman, Votruba-Drzal, El Nokali, Nermeen, \& Castle, 2015, p. 896). In several countries, the task to support student learning is considered as a challenge for teachers and has been identified as the core for further professional development (Schleicher, 2012).

Furthermore, students that do not meet standards or lack the desired competencies or knowledge are talked about in neoliberally governed schools as being threats to future prospects for individuals, education, and society (Bagger, 2016). One example of this is how the Programme for International Student Assessment (PISA) ${ }^{1}$ evaluates the skills and competencies of 15 -yearolds that are deemed to be needed in adult life (OECD, 2017). This measure involves comparison and ranking between countries and also engines educational policy change (Grek, 2009; Kim,

\footnotetext{
${ }^{1}$ PISA is an Organisation of Economic Co-operation and Development (OECD) project that measures 15-year olds' knowledge every third year.
} 
Bagger, A. \& Roos, H. (in press). The shared duty of special educational support in mathematics: borders and spaces in degree ordinances for pre-service teachers. In N. Radakovic \& L Jao (Eds.), Borders in Mathematics Pre-Service Teacher Education. Springer. Authors copy.

2017). This is an example of an international, goal-oriented, marketing trend of schooling for connecting results with quality and accountability (Rönnberg, 2011). A consequence of international monitoring surveys and national testing is adjustments to education and policy decisions on a national level (Dreher, 2012; Luke, 2011; Martens, Knodel, \& Windzio, 2014; Pettersson, 2008; Wrigley, 2010). This reasoning is also applied to different pre-service and inservice teacher education programs and policies in order to improve teachers (Lincove, Osborne, Mills, \& Bellows, 2015). To summarise, students that do not reach learning targets in the curricula are consequently labelled as "low achieving" students. Subsequently, these students' results are often attributed to flaws in the education system and accountability issues of the school and ultimately, teacher education.

There are questions regarding who students in needs of support in mathematics really are and what support for these students should or could look like (Lewis \& Fisher, 2016), as well as how it differs between schools and across countries. Nevertheless, disadvantaged groups in mathematics are often connected to identity categories, such as gender, race, class, and ethnicity, and there is a challenge for teachers and schools to embrace these categories (Bishop, Tan \& Barkatsas, 2015). Teacher training is meant to prepare future teachers for fruitful collaboration in order to prepare them to support students with special educational needs. Such training aims at supporting inclusive settings:

Internationally, standards related to teaching and teacher preparation have reflected the expectation that general and special education teachers ought to be prepared to collaborate with each other to meet the needs of students with [special educational needs] in inclusive settings (Van Ingen, Eskelson, \& Allsopp 2016, p.74.)

Promoting this inclusive stance has been a challenge for teacher training programs. If positive attitudes towards the inclusive approach are not developed, this stance will eventually diminish in teachers' practices in mathematics classrooms (Shade \& Stewart, 2001). In addition, how well this collaboration plays out will affect how students in need of support are educated and is ultimately regulated through the goals in the professional exam. For example, preparation on how to collaborate is needed and has to be executed in a way that takes both mathematical knowledge and special educational knowledge into account at the same time.

How educational professions involved in providing special support are organised and work together, varies between countries (Göransson, Lindqvist, Möllås, Almqvist, \& Nilholm, 2017). In Sweden, special education teachers and mathematics teachers for primary school (MTPs) are the main professionals involved in giving support to all students (including those in need of support) in mathematics in primary school. MTPs are trained as generalists and are responsible for teaching all subject areas, not just mathematics. In Sweden, only teachers who have passed an exam in mathematics are allowed to assess students' mathematical knowledge thus in all schools, students have at least one teacher who has a mathematical background. Special education teachers have different specialisations, including mathematics, whom we will refer to as special education teachers in mathematics (STms). STms have pre-service training in both the subject of mathematics, and to a varied degree, special education and knowledge of special needs. STMs do not have their own classes. They sometimes, but not always, have an office or a room in which 
Bagger, A. \& Roos, H. (in press). The shared duty of special educational support in mathematics: borders and spaces in degree ordinances for pre-service teachers. In N. Radakovic \& L Jao (Eds.), Borders in Mathematics Pre-Service Teacher Education. Springer. Authors copy.

they collaborate with classroom teachers to work with students in need of support. It is also common for STms to co-teach with mathematics teachers in the classroom.

A division is typically seen between MTPs and STms for two reasons: 1) STms often give support directly to students in order to supplement the teaching provided by MTPs, and 2) STms also give consultations to MTPs in order to help them to develop, adjust and improve their teaching of students in need of support (Sundqvist \& Ström, 2015). These are common practices in both Finland and Sweden. In a Finnish context, these kinds of consultations were found to consist of mainly three different types: consultation as counselling, reflective consultation, and cooperative conversations. According to Sundqvist and Ström (2015), the counselling type of consultation is a mainly expert driven approach to consulting and consists of classroom teachers getting transference of special educational knowledge in the shape of information, advice or suggestion. Reflective consultations are instead participant driven and are more like a stimulating, exploratory conversation in a search for developmental areas and problems to handle through a process of learning that are often relational, social or system-oriented. Cooperative conversations are conversations in which professional exchange takes place and both parties mutually benefit. Sundqvist and Ström (2015) found all three forms of consultation to be beneficial for various purposes, and that it was essential that each was used in a knowing and reflective way. Consulting counselling are more prominent if the teachers involved are recently educated and lack experience. What limits the teachers is the transferral of knowledge, the student being in the core rather than a system-oriented approach towards challenges, and the risk of the STms' knowledge and interpretations taking over and becoming predominant (Sundqvist \& Ström, 2015). Internationally, it has also been shown that teacher education programs do not prepare STms and MTPs for consultations that focus specifically on mathematics, mathematical contexts, and student participation (Van Ingen, Eskelson \& Allsopp, 2016).

Even in a Swedish context, consultations were found to be important (Roos, 2015). Here, the different spaces where STms work is understood by using Wenger's (1998) notion of communities of practice (COP). A CoP is a social practice with mutual engagement between members. STms have a complex mission, they participate in many CoPs at the same time (such as with MTPs and other STms), and are brokers between CoPs. Hence, special education teachers struggle to find both the time and the space to carry out this brokering and have consultations with MTPs.

Holgersson and Wästlid (2018) revisited the specialized work of the mathematical development of students in need of support and stated that foundational to STms' duties is to secure organisational prerequisites for all students to learn mathematics. They also described the following as important competencies for STms: pedagogical content knowledge, knowledge of how mathematics is learned and how development in the subject can and should appear, and knowledge about the obstacles encountered by students in need and the ways to overcome these obstacles. Accordingly, STms work directly with students in need by providing special support and facilitating to development of their learning environment. The latter means that approaches, relations, teaching materials, and methods are the main focus for development, and this occurs at three levels: at the individual, group and organisational level. Thus, it is important for STms to hold consultations with teachers or other school professionals, as well as to make sure that the school has systems for monitoring and securing the mathematical development of all students. With this said, STms are typically not the ones assessing or analysing individual students' results. 
Bagger, A. \& Roos, H. (in press). The shared duty of special educational support in mathematics: borders and spaces in degree ordinances for pre-service teachers. In N. Radakovic \& L Jao (Eds.), Borders in Mathematics Pre-Service Teacher Education. Springer. Authors copy.

Rather, their responsibilities are often organizational. Then again, it is also quite common for STms to perform some of the trickier or more difficult cases to evaluate or to complete teacher assessments in some way (Holgersson \& Wästlid, 2018).

Holgersson and Wästlid (2018) have further described that the duties at the group and organizational levels are not prioritized by the school management in terms of developing learning environments and consulting teachers regarding the educational methods, content, and strategies. The phenomenon of STms having difficulties working on organizational issues of development and as consultants has also been identified in a survey of special education teacher training and occupation (Göransson, Lindqvist, Klang, Magnusson, \& Nilholm, 2015). The survey points towards this profession as serving a governmental quality function and as a guardian of relational approaches toward learning and inclusion in schools in Sweden, but lacking in authority. In Sweden, teaching is approximately $50 \%$ of the duties of special education teachers. Furthermore, the Education Act of Sweden (SFS 2010:800) does not mention special education teachers to be a necessary part of health care teams, unlike nurses, psychologists, or school social workers. In Sweden, school social workers work for students' well-being on several levels and collaborate with professionals within and outside the school, and are not the same as municipality social workers that investigates families, for example. If students need someone besides their friend, teacher or parent to listen to them, or if students are absent, are involved in bullying or some other disruptive behaviour - the school social worker might become involved (for more reading see for example Isaksson \& Larsson, 2017). When it comes to the special educational competence that should be available in the health care team, it is not made explicit what kind of profession or degree, is required. The jurisdiction of special education teachers thus becomes hard to identify, and there is a discrepancy between what is expected from schools and what is expected from a political stance. Göransson et al. (2015) conclude that the role of special education teachers can rather be seen as an expression of educational policy formulated in terms of a new vocational degree.

\subsection{Aim of the chapter}

Professionals, in this case STms and MTPs, are supposed to collaborate and intersect with each other, in order to provide support to students in need of support. Aspects that constitute and effect the efficacy of this collaboration include:

1) The kinds of knowledge pre-service training affords about the "other" profession (MTPs for STms, and vice versa)

2) Whether the goals in the degree ordinance for the two professions' pre-service training are in harmony with each other; and

3) How these goals lead to a shared understanding of the assignment, and a joint and solid base of knowledge on the shared assignment to support students in need of support in mathematics.

Hence, the aim of this chapter is to contribute knowledge of borders, spaces, and intersections between two pre-service teacher professions that will cooperate in their future teaching: STms and MTPs. This knowledge is constructed by exploring some of the prerequisites for the OTL about 
Bagger, A. \& Roos, H. (in press). The shared duty of special educational support in mathematics: borders and spaces in degree ordinances for pre-service teachers. In N. Radakovic \& L Jao (Eds.), Borders in Mathematics Pre-Service Teacher Education. Springer. Authors copy.

the shared duties to provide special education mathematics to students through the goals of teacher exams in Sweden. The research question is, how does the degree ordinance depict the duties of the teacher, the "other" profession, and their future shared task of providing support to students in need of support?

\section{Methodology}

The case of Sweden is situated in an educational national context that is framed by curricular goals in the Higher Education Ordinance, which create OTL for pre-service teachers. OTL are understood as being constituted partly by exams, and the goals of the exams constitute borders between different kinds of teachers regarding their duties to support students in need of support in mathematics. OTL have been connected to how goals in curricula are reached and measured (Stobart, 2009). It also includes a stance of caring for equal access to fair and meaningful learning for all students, and is then socioculturally constructed as emerging from the interplay between learning environment and the individual (Moss, Pullin, Gee, Haertel, \& Young, 2008). OTL within mathematics education have been researched based on the idea that various contexts and systems affect these opportunities (Lester, 2007). Early on, the focus of OTL was often on how goals in curricula were possible to reach, while later research has focused on effects connected to issues of intersectionality and how different learners and groups of learners are affected by the curricula and other system-oriented issues (Lester, 2007). This chapter explores the patterns, intersections, and borders between goals in the exams for pre-service teachers. OTL are provided for pre-service teachers, who are the focus of the goals in their exams. At the same time, students in need of support in mathematics are a special group of students that could be affected by the explored goals.

\subsection{The context of the study}

The Swedish context of higher teacher education is briefly described to facilitate the contextual reading of the results, conclusions, and discussion. STm and MTP exams lead to a Bachelor's degree. Teacher exams - and other university exams for that matter - are regulated by a degree ordinance in which the demands for degrees are set in the Higher Education Ordinance (SFS 1993:100). The ordinance includes the following headings: extent, goal, prerequisites, and what is required in order to achieve a degree certificate. The requirements for achieving a certificate are specified as the achievement or demonstration of knowledge in three qualitatively different areas: 1) knowledge and understanding, 2) competence and skills, and 3) judgement and approach (SFS 1993:100).

In Sweden, there are two types of teacher education programs for primary school: one for preschool-class ${ }^{2}$ (6-year-old students) to grade 3 (9-year-old students), and one from grade 4 (10year-olds) to grade 6 (12-year-olds). Both are four years long. There are also two types of training to become a mathematics teacher in secondary school: one for grade 7 (13-year-old students) to grade 9 (16-year-old students) which is 4.5 years long, and one for upper secondary school which

\footnotetext{
${ }^{2}$ In Sweden, there are two forms of education prior to formal schooling: 1) a daycare form of preschool (for 1-5 year olds) and 2) a preschool-class that is part of the school system (as described in this chapter)
} 
Bagger, A. \& Roos, H. (in press). The shared duty of special educational support in mathematics: borders and spaces in degree ordinances for pre-service teachers. In N. Radakovic \& L Jao (Eds.), Borders in Mathematics Pre-Service Teacher Education. Springer. Authors copy.

is 5 to 5.5 years long (a voluntary school in which students are usually 16-19 years old). In Sweden there are two programs for teachers who wish to specialise in special education. One to become a special pedagogue and another to become a special education teacher. Each program is 1.5 years in length (at an advanced level) and results in a different teaching degree. Both programs require a prior teaching degree, as well as three years of working in the profession. The special education teachers program has different specializations, for example: reading and writing development, and mathematics development. The special pedagogue program works primarily with development of the school, learning environment, teachers' competence - and also with students - but is not specialised within a subject or disability. In this paper, we explore the degree program for STms, and the MTP exams for preschool-class to grade 3, grades 4 to 6 , and grades 7 to 9 respectively. In other words, these teachers will support and teach students from ages 6 to 16 in mathematics. Sometimes, the STms will be labelled more generally as special education teachers, since all special education teachers share degree ordinance and thereby most of the goals, except for the specialised goals concerning mathematical development.

\subsection{Method of analysis}

We have performed a systematic qualitative content analysis (Feucht \& Bendixen, 2010) of the degree ordinance attached to the higher education ordinance. The investigation of the qualitative goals in these bachelor exams focused on: 1) knowledge and understanding, 2) competence and skills, and 3) judgement and approach. The content was framed in relation to the research questions, and the steps of the analysis procedure were taken from Feucht and Bendixen (2010). Statements connected to the duties of the teacher, the "other" profession, and the future work description regarding the mission to provide support were first selected from the three areas of qualitative goals. The statements were then grouped in regard to similarities in content, and the groups were given explanatory paraphrases as labels signalling what was in common, such as assessment, learning, development, disabilities, and organization. Finally, groups of statements and statements within groups were compared in regard to how they constituted borders, spaces, and intersections related to their shared duties.

The analysis was performed in close connection to the labelling of goals, or levels of knowledge demands, in the degree ordinance, and the result is presented accordingly. These labels are in common for all degrees in the Higher Education Ordinance, constitutes the knowledge deemed to be desirable and needed in order to work independently with the actual profession and thereby also depicts OTL described in this steering document. It is important to pay attention to the nuances in knowledge that are displayed in the goals. For example, nuances might be insights, knowledge, deeper knowledge, or understanding, which could signal a variation in the depth or quality of knowledge. Sometimes, the knowledge is something that is supposed be shown in assignments during their training, while at other times, it is something that the teacher is supposed to have. It is also important to remember that the STms have always undertaken some basic teacher training, and a teaching degree is a prerequisite for undertaking education to become a special education teacher. This implies that it is possible for STms to be preschool-class teachers with additional mathematics education, subject teachers in mathematics from secondary or upper secondary school, or to have completed one of the two 
Bagger, A. \& Roos, H. (in press). The shared duty of special educational support in mathematics: borders and spaces in degree ordinances for pre-service teachers. In N. Radakovic \& L Jao (Eds.), Borders in Mathematics Pre-Service Teacher Education. Springer. Authors copy.

teacher exams investigated in this chapter, namely to become preschool-class to grade 3 teachers or grades 4 to 6 teachers.

\section{Borders, spaces, and intersections}

Swedish acts, ordinances, and government agency regulations are published in The Swedish Code of Statues (SFS). The references for education acts, Higher Education Ordinance etc. is therefore SFS followed by the identification number of the actual document ${ }^{3}$. Documents in The Swedish Code of Statues (SFS) are digitally published without page-numbers. The results and analysis is built as a narrative of the OTL about special support in mathematics within the degree ordinances for STms and MTPs, and between those ordinances. The degree ordinances are part of the Higher Education Ordinance (SFS 1993:100). This regulates the teacher training at universities, not to be confused with the Education Act (SFS 2010:800), which regulates the education in schools. In other words, teacher training is regulated in the Higher Education Ordinance and when they thereafter work as teachers in compulsory school, their works and the education they provide, is regulated by the Education Act. The identified themes were explored under three levels of knowledge demands, or labels of goals, stated in the degree ordinance, which in turn illuminated borders, spaces, and intersections between the exams. Important to remember is that all special education teachers share the same degree ordinance, there are some but very important specific goals within that, that differs in regards to specialisation and that decides the specialisation in the program, and what degree is reached by studying it. Therefore, when the text depicts things that are in common for all directions of special teacher programs, it is marked with the abbreviation "ST" while, if the text concerns only the special direction of mathematics, the abbreviation "STm" is used. An overview of the main findings is displayed in Table 1.

Table 1. Overview of analytical strategy and main findings

\begin{tabular}{|c|c|c|c|}
\hline $\begin{array}{l}\text { Area of goals } \rightarrow \\
\text { Brief overview } \\
\text { of analysis } \downarrow\end{array}$ & $\begin{array}{l}\text { Knowledge and Understanding } \\
\text { Foundation }\end{array}$ & $\begin{array}{l}\text { Competence and Skills } \\
\text { Direction }\end{array}$ & $\begin{array}{l}\text { Values and Judgment } \\
\text { Focal points }\end{array}$ \\
\hline $\begin{array}{l}\text { Themes in } \\
\text { common }\end{array}$ & $\begin{array}{l}\text { A historical perspective } \\
\text { Development or learning } \\
\text { Assessment and grading }\end{array}$ & $\begin{array}{l}\text { Foundations } \\
\text { Development of practice } \\
\text { Development of student } \\
\text { knowledge }\end{array}$ & $\begin{array}{l}\text { Focal point of the } \\
\text { profession hubs } \\
\text { Ethics as a foundation }\end{array}$ \\
\hline Interpretation & $\begin{array}{l}\text { ST Guardian of educational } \\
\text { discourses and structures. Carrier of } \\
\text { explicit knowledge of disorders. } \\
\text { Monitoring the process of } \\
\text { assessment. } \\
\text { MTP Carrier of present knowledge of } \\
\text { the individual students' learning (F-3) } \\
\text { or development (4-6) in math, and } \\
\text { assessment. }\end{array}$ & $\begin{array}{l}\text { ST To cooperate, advise, } \\
\text { lead, participate, and be } \\
\text { critical. } \\
\text { MTP To cooperate, } \\
\text { follow, develop, and be } \\
\text { developed }\end{array}$ & $\begin{array}{l}\text { ST Human rights, } \\
\text { collaboration with other } \\
\text { professions and schools } \\
\text { The hub of the supportive } \\
\text { work. } \\
\text { MTP Children's proper and } \\
\text { sustainable development } \\
\text { The hub of the classroom }\end{array}$ \\
\hline
\end{tabular}

\footnotetext{
${ }^{3}$ For more information see https://svenskforfattningssamling.se/english.html
} 
Bagger, A. \& Roos, H. (in press). The shared duty of special educational support in mathematics: borders and spaces in degree ordinances for pre-service teachers. In N. Radakovic \& L Jao (Eds.), Borders in Mathematics Pre-Service Teacher Education. Springer. Authors copy.

\subsection{Knowledge and understanding}

The goals regarding knowledge and understanding are one of the foundations in future professional practice. Three themes emerged: 1 ) a historical perspective; 2 ) duties to work for learning; and 3) development, assessment, and grading. Regardless of professional degree (STms or MTPs), teachers are supposed to have insights into relevant research and development work. The criteria for relevance are not stated, but they can be assumed to relate to the other goals and the purpose of the exam.

\section{A historical perspective}

STms should have knowledge regarding students in need of support from a historical perspective, as well as deeper knowledge regarding learning in mathematics (SFS 1998:100). MTPs should also have knowledge regarding historical aspects, but not the explicit history of students in need of support but rather the history of schooling (SFS 1998:100). This situation is interpreted as STms being responsible for ways (both successful and not) that have been used to support students in the school system and organization, as well as the ones who foresee future implications in terms of teaching approaches, methods, or materials. This is in contrast to MTPs who are supposed to know about the history of schooling, but without explicit knowledge of the possibilities and pitfalls that might derive from the history and culture of the education system. This makes the special education teacher a guardian of sustainable development of the teaching discourses of students in need of support and creates a shared area of historical awareness. It also creates a limitation between the teaching roles in regards to the focus and possibilities to share understanding in their duties to support students in need of support in mathematics.

\section{Learning and development}

MTPs should have knowledge regarding children's and students' development, needs, and prerequisites required for teaching and learning. However, this is not explicitly related to students in need of support, or the subject of mathematics. Additionally, this could also be interpreted as the knowledge needed being subject-specific. MTPs are also supposed to show knowledge in didactics and methods that are required in the subject of mathematics and in general. MTPs of younger students (preschool-class to grade 3 ) should also display deeper knowledge in regard to learning mathematics, as well as children's communication and development in general and in language. Teachers of grades 4 to 6 are not expected to display knowledge of students' learning, instead the goal is aimed at reaching deeper knowledge regarding mathematics development. Interestingly, MTPs for preschool-class to grade 3 are supposed to know about learning in mathematics, while MTPs for grades 4 to 6 are supposed to know about development. This indicates that learning comes first, and knowledge in mathematics might be developed thereafter, as if there is no knowledge in mathematics before that. Of course, knowing about students' prerequisites for learning and what is demanded for teaching, could very well include teachers' knowledge of their mathematical knowledge. But again, this is not stated.

As for STms, the goals are combined in general terms of learning and development, although not specifically in relation to the subject of mathematics, but rather for students with disabilities: "Demonstrate deeper knowledge of the development and learning of children and pupils and demonstrate knowledge of the development and learning of children and students with disabilities, including neuropsychiatric disorders" (SFS 1998:100). Additional knowledge 
Bagger, A. \& Roos, H. (in press). The shared duty of special educational support in mathematics: borders and spaces in degree ordinances for pre-service teachers. In N. Radakovic \& L Jao (Eds.), Borders in Mathematics Pre-Service Teacher Education. Springer. Authors copy.

about neuropsychiatric disorders was recently added in 2018. This constructs STms as the carrier of knowledge of disabilities, and especially neuropsychological disabilities. Furthermore, there is a border between STms and MTPs since the latter's goals do not include knowledge of students with disabilities but rather subject-specific learning and development. Therefore, the professions must combine their knowledge so that both the subject-specific knowledge of learning and development and the knowledge of disabilities come into play. Very often, STms work together with teachers when a student advances from grade 3 to 4 , and in those cases, STms become the guardian of the progression in learning and development for students with disabilities.

\section{Assessment and grading}

Preschool-class to grade 3 MTPs are supposed to obtain and demonstrate "deeper knowledge of the assessment of student learning and development" (SFS 1998:100), which is not explicitly in the context of mathematics but can be compared to what these teachers are supposed to know about the students in mathematics, namely deeper knowledge of student learning. However, these MTPs are also supposed to have knowledge (if not deeper knowledge) in general regarding students' development. Thus, the assessment is framed in relation to development for the preschool-class to grade 3 teachers. For grade 4 to 6 teachers, however, the assessment is framed in relation to grading and as a display of deeper knowledge: "show deeper knowledge in assessment and grading" (SFS 1998:100). It is relevant to go back to what kind of focus that grades 4 to 6 teachers should have in students' mathematical learning: their development. This is not mentioned in relation to assessment and grading, as opposed to the knowledge in assessment of learning and development for preschool-class to grade 3 teachers. Finally, STms are also supposed to "display deeper knowledge of assessment issues and grading" (SFS 1998:100), implying that STms should understand and be able to promote and support the teachers working with assessment. When looking at issues in assessment, STms appear to exist in the shared space of both assessment and grading and can therefore work together with MTPs by providing support. At the same time, the words "assessment issues" (SFS 1998:100), imply that STms might be the ones keeping watch over the borders of the duties to assess and grade.

\subsection{Competencies and skills}

The competencies and skills that could be most central for providing support for students might be the ones that ensure that this goal is actually a focus in carrying out the teacher's duties. Notably, in regard to the competence and skills of teachers, "mathematics" is mentioned only twice, and that is in the STms' goals and not in the MTPs'. If interpreting this positively, the subject and duties to provide support to students in need of it, is included in "having the subject knowledge needed to teach" and "apply subject didactics and methods needed for teaching and learning" (SFS 1998:100). The goals for preschool-class to grade 3 and grades 4 to 6 teachers that can be connected to the shared duties to give support are the same. We understand the STms' ability to support and develop both students and learning environments independently is understood as the core: "show ability to support students and children and to develop learning environments in the school" and to "demonstrate the ability to independently carry out, followup and evaluate as well as lead the development of the educational work with the aim of meeting the needs of all children and students" (SFS 1993:100). In the MTP exam, instead of "independent work", there is a strong emphasis on collaboration in the duties to provide support. The task is 
Bagger, A. \& Roos, H. (in press). The shared duty of special educational support in mathematics: borders and spaces in degree ordinances for pre-service teachers. In N. Radakovic \& L Jao (Eds.), Borders in Mathematics Pre-Service Teacher Education. Springer. Authors copy.

expressed as an act of "handling special needs" (SFS 1993:100). The goals also stress that the teaching duties must derive from and communicate equity in the form of core values: "demonstrate the ability to identify and, in collaboration with others, handle special educational needs", and "demonstrate the ability to consider, communicate and anchor equality perspectives in the educational activities" and "demonstrate the ability to consider, communicate and anchor core values including human rights and democratic values in the educational activities" (SFS 1993:100). There are no differences between the preschool-class to grade 3 and grades 4 to 6 teachers in these statements.

The intersection between STms and MTPs is understood here as STms promoting, analysing, developing, and challenging the learning environment, and thus challenging MTPs' practices. MTPs are instead obliged to communicate, cooperate, and be receptive in their work in which special needs are handled. Notably, mathematics as a subject is not mentioned explicitly, and the emphasis that MTPs should cooperate and communicate does not have a counterpart in the STms' goals. Overall, providing support is depicted as being carried out in two specific directions of development: 1) development of the learning environment and 2) development of students' knowledge.

\section{Developing the learning environment}

The STms' duties are twofold, and in the part of developing learning environments, STms are depicted as free, critical, and able catalysts of change and improvement. At the same time, STms are supposed to do this independently, but also while "participating" in teaching. The previous section stated that STms should work independently whilst MTPs should cooperate. Participating is not the same as cooperating. What is actually meant by the learning environment is not stated, but this often means the teachers, teaching methods, materials. As such: STms should "demonstrate the ability to critically and independently initiate, analyse and participate in preventive work and help to eliminate obstacles and difficulties in different learning environments" (SFS 1998:1003). Correspondingly, this development work rests in STms' abilities to do educational investigations, which seem to be slightly different from working on preventive measures and eliminating obstacles and difficulties. This is interpreted as an educational investigation being acted out only after difficulties have already happened, and despite all the literature depicting the power of building on what is strong, functional, and works, preventive work has a kind of dystopian stance. Furthermore, when the difficulties are already apparent, the student is perceived as a passive object and that the student has difficulties, even though they appear, or maybe even "come into existence", in the student's encounter with the environment. STms should "demonstrate [an] in-depth ability to critically and independently carry out educational investigations and analyse difficulties for the individual in the learning environments where the child or the student is taught and staying during preschool-class or school day" (SFS 1993:100).

These goals of STms stand in contrast with MTPs' goals regarding competence and skills. In this case, the development of the environment rests rather on the ability to reflect on their own and others experiences. In the following expression of "others", STms are to "demonstrate an in-depth ability to critically and independently utilize, systematize and reflect on the experiences of their own and others" (SFS 1993:100). Furthermore, MTPs should work towards deeper learning and developing their own knowledge and skills in order to teach and support all 
Bagger, A. \& Roos, H. (in press). The shared duty of special educational support in mathematics: borders and spaces in degree ordinances for pre-service teachers. In N. Radakovic \& L Jao (Eds.), Borders in Mathematics Pre-Service Teacher Education. Springer. Authors copy.

students, as described by the following: "demonstrate in-depth ability to create the conditions for all students to learn and develop" (SFS 1993:100). Here, it is taken for granted that students in need of support in mathematics are included among "all students", in the same way that we took for granted that the STms are included in "others". Interestingly, the STms do not have the target of reflecting on their own knowledge and being oriented towards developing it, but rather others' knowledge. This is an aspect of the future shared tasks where the borders between the examined occupations (ie. STms and MTPs) might appear clearest, namely in regard to their perspectives of their own and shared experiences and knowledge.

\section{Developing students' knowledge}

STms' goals are constructed as a mechanism of assessing and reviewing assessments of mathematical development (probably made by teachers). However, mathematical knowledge or learning is not mentioned in the assessment perspective: "the student should also demonstrate the ability to critically review and apply methods for assessing [...] children and students' mathematical development" (SFS 1993:100). Furthermore, cooperation on behalf of STms is finally stressed, as it is needed in establishing and implementing action plans for supporting students in need: "to participate in and in cooperation with stakeholders work to establish and implement action plans for individual students" (SFS 1993:100). Furthermore, some part of the action plans or teaching of students in need of support can be the duties of STms, as individualised approaches should be a foundation in the knowledge of STms. STms should "demonstrate a profound ability for an individualized approach for children and students in need of special assistance" (SFS 1993:100).

In comparison, MTPs' duties are to have knowledge to stimulate learning for all. Again, it is not certain that this is perceived as also including students in need of support in mathematics. As described in the degree ordinance, "MTPs should demonstrate the ability to acquire knowledge of and experience with students to stimulate each student's learning and development" (SFS 1993:100). The MTPs' ability to cooperate is also stressed in the process of planning, evaluating, and developing teaching for all students and students' individual learning. They must: "demonstrate the ability to independently, together with others, plan, implement, evaluate, and develop teaching and teaching activities in general to optimally stimulate the learning and development of each student" (SFS 1993:100). It can be guessed that in the "together with others" part, other school professionals such as STms might be included, but this is not explicitly said. Regarding cooperation, parents and students are mentioned in the context of supporting the individual students' learning, but other professionals within the school are not required to: "demonstrate the ability to observe, document, analyse, and assess students' learning and development in relation to the goals of the school and to inform and collaborate with students and their guardians" (SFS 1993:100).

To sum up, cooperation is stressed in both STms' and MTPs' ordinances, but it is not explicitly said whether the "other" profession is included as a partner in this cooperation. Although, it can be assumed that this is the case. This is more likely in the situation of developing teaching and less likely in the supporting of each student (including students in need). According to the goals stated, STms are supposed to have the ability to stimulate learning for students in need of support, which can thus be understood as a single-handed mission of STms. This contrasts with the consultant conversations that STms are also supposed to be able to hold, as well as the 
Bagger, A. \& Roos, H. (in press). The shared duty of special educational support in mathematics: borders and spaces in degree ordinances for pre-service teachers. In N. Radakovic \& L Jao (Eds.), Borders in Mathematics Pre-Service Teacher Education. Springer. Authors copy.

critical and developing approach to teaching. In this circumstance, mathematics is mentioned for a second time: "demonstrate the ability, depending on the specialization chosen, to be a qualified call partner and adviser in matters relating to mathematics difficulties".

\subsection{Judgement and approach}

The third area of demands in the exam concerns judgment and approach. Here, the values underlying the Swedish Education Act, and which the teachers are assumed to work to fulfil when they later are employed at teachers, are put to the fore. These values are understood as secured and governed through the decision to educate teacher professionals towards them.

There are both similarities and differences between the teacher exams, and they manifest under two themes: 1) ethics, which is constructed as an underlying fabric in the teacher professions, and 2) hubs, which point towards the connection or core in the duties. Mathematics is not mentioned, nor is there any difference between the two kinds of MTPs, the ones teaching preschool-class to grade 3 and the ones teaching grades 4 to 6 . The MTPs' goal of developing and reflecting on their own knowledge and experiences, as well as that of other professionals, is considered to be a competence and skill. For STms, the ability to identify needs to develop knowledge and competence is stated as a goal within the area of judgment and approach.

\section{Ethics}

Both STms and MTPs have to be able to "demonstrate self-knowledge and empathetic ability" (SFS 1993:100). In order to demonstrate empathy, teachers must know oneself and be able to self-reflect. This also applies to assessment, in which teachers are supposed to exploit, foresee, and detect social and ethical aspects. However, a difference is that STms are encouraged to retrieve these ethical insights from human rights, whilst MTPs are encouraged to retrieve these ethical insights from the students' rights in particular, and the UN Convention on the Rights of the Child (United Nations, 1989)The ethics also relies on the assessment being based on a scientific perspective as teachers should: "demonstrate the ability to make assessments based on relevant scientific, social and ethical aspects with particular regard to [...] human rights" or "in particular the child's rights under the Child Convention and sustainable development" (SFS 1993:100).

\section{Hubs}

Connected to judgement and approach is collaboration with other professionals and schools, which is stressed as a requirement for STms. Collaboration was already highlighted as a competence and skill for MTPs. Since the stakeholders are not explicitly defined, it might be assumed that what are intended here is not primarily professionals within the school, but other professionals from the student health team at the school, which includes school nurses, school psychologists, school social workers, principals, and special education teachers. Additional collaborators include other types of schools, such as schools for mentally disabled students ${ }^{4}$, Sámi

\footnotetext{
${ }^{4}$ In Sweden there are specific schools for mentally disabled students with its own curricula.
} 
Bagger, A. \& Roos, H. (in press). The shared duty of special educational support in mathematics: borders and spaces in degree ordinances for pre-service teachers. In N. Radakovic \& L Jao (Eds.), Borders in Mathematics Pre-Service Teacher Education. Springer. Authors copy.

schools ${ }^{5}$ or special schools ${ }^{6}$, and external medical professionals such as pedagogues for visually disabled students, child psychologists or professionals working with rehabilitation. Since this aspect of collaboration is not stated for the MTPs, STms are designated as the hub connecting organisations and professionals surrounding the student, as opposed to the teacher, who is the hub in the classroom at school.

\section{Conclusions and implications}

The differences, similarities, and overlaps between the pre-service teacher training for STms and MTPs are understood as constituting important borders and spaces in future work to give students support in mathematics. These borders and spaces impact how well-prepared teachers are to collaborate in the shared task of supporting students in need in the subject of mathematics. This study has the potential to contribute to a deeper understanding of pre-service teacher training and its opportunities and threats in preparing for a school that can provide equal and high-quality teaching of students in need of support in mathematics. The key findings show that the borders and intersections are created mainly through placing responsibility, concerns, location of teaching and duties as well as directing ways of relating to their own and the "other" profession. Tensions between aspects of teaching and learning have emerged, regarding for example the order between learning and knowledge, the history and the present, the classroom and schools' development, assessment as a process or product and learning for all or individualised learning. The resulting friction and synergy, will be briefly discussed below.

On July $3^{\text {rd }}, 2018$ there was a change in the Higher Education Ordinance (SFS) in Sweden regarding the qualitative goals for pre-service STms. This change implicates a display of specific knowledge of neuropsychological disabilities. What has not changed is the overall goal of the education, which can be interpreted as STms working mainly individually with students. As described in the degree ordinance, "The student should demonstrate the knowledge and ability demanded in order to work independently as a special education teacher for children and students [...] in need of support [...] in mathematical development" (SFS 1993:100). The Education Act (SFS 2010:800), however, remains the same in regard to special education support. In practice, this means that any kind of professional with special educational knowledge with 90 credits of specialized education (not just STms) might be the one assisting the health care team or MTPs to provide support to students in need of support. This is troublesome since earlier research shows that development work at the group and organizational levels is needed in order to secure inclusion and learning for every student, and at the same time, the authority of the special education teacher is weak (Göransson et al. 2015; Holgersson \& Wästlid, 2018). The changes in steering documents are now giving STms even more responsibilities and explicit skills, but without strengthening their authority through school legislation.

The blurred authority and responsibility of special education teaching implies that the borders, intersections, and limits of STms and MTPs must be negotiated between the professionals in every municipality and school. The collaboration in practice is partly decided by

\footnotetext{
${ }^{5}$ A school form in parallel with Swedish compulsory school, but with its own curricula, for children who are Sámi (the indigenous people of Sweden).

${ }^{6}$ In Sweden there are special schools for students with certain exceptionalities (for example, autism). These schools follow the curricula of the Swedish compulsory school.
} 
Bagger, A. \& Roos, H. (in press). The shared duty of special educational support in mathematics: borders and spaces in degree ordinances for pre-service teachers. In N. Radakovic \& L Jao (Eds.), Borders in Mathematics Pre-Service Teacher Education. Springer. Authors copy.

school principals in terms of what tasks should be performed by which professionals. The general and sweeping labels in the higher education ordinance regarding the knowledge and cooperation that are needed in providing special support do not help with the division of labour. We believe that the generalized way of stating the goals in teacher education when it comes to collaboration, roles, and shared responsibilities can actually hinder future collaboration.

Looking at the borders, limitations, and intersections of the goals for pre-service teachers, aspects such as the source, direction, and focal points of knowledge appear to be essential. STms are defined as someone who has responsibility for the historical and future perspectives on students in need of support, whilst the MTPs' responsibilities are placed in the present to a high degree. This creates borders between STms and MTPs by placing them in different spaces in time. This also puts an expectation on STms to be a broker between spaces, time, and teachers teaching preschool-class to grade 3 and grades 4 to 6 . In addition, it is quite obvious that STms are the carriers and guardians of explicit knowledge about special needs and disabilities and that they are assumed to work with, and promote the development of mathematical knowledge both with students in need of support, and also supporting all students' learning through promoting development in the organization. The responsibility and ability to carry out these responsibilities are connected to leading, working independently, and having a historical and critical perspective of the school's work with these issues. Furthermore, MTPs are also supposed to be challenged and supported with knowledge about students' mathematical knowledge, obstacles, and ways forward.

Interestingly, STms are not directed to have a critical stance towards their own knowledge nor to be reflective in their listening to other teachers' knowledge, which is the case with MTPs. A challenge lies in moving from the role of a teacher to the role of an expert, especially since teachers are often used to working in teams and collaborating, as indicated in the goals of the pre-service teacher training. Something that is not highlighted in the degree ordinances is a goal connected to co-teaching (see for example, Weiss, Pellegrino, Regan, \& Mann, 2015; Van Ingen, Eskelson, \& Allsopp 2016). This gives the impression that when collaborating, STms should lead and that perhaps MTPs should follow. Then, according to the goals depicted in the degree ordinance, the collaborative stance with collegial learning spaces seems to disappear when training STms. Hence, the goals create a border of diversity, segregation, and perhaps loneliness or superiority, which might create socioemotional hindrances for future collaborations between these two occupations. Furthermore, the loneliness of the STms implies that they need to seek collaborations outside their own school to promote their development (since there most often is only one STm at a school), in networks in their community, and with universities. Pre-service teacher training could give all pre-service teachers a deeper knowledge of each other's duties and also the possibility of taking shared courses, which might help them begin to make plans and negotiations, collaboration, learning, teaching, leading, and following. This could make teachers' shared duties to support students in need of support in mathematics easier when these preservice teachers enter into the profession, and the possibility to maybe even engage in coteaching.

\section{References}


Bagger, A. \& Roos, H. (in press). The shared duty of special educational support in mathematics: borders and spaces in degree ordinances for pre-service teachers. In N. Radakovic \& L Jao (Eds.), Borders in Mathematics Pre-Service Teacher Education. Springer. Authors copy.

Bagger, Anette (2016). Quality and equity in the era of national testing. The case of Sweden. In Julie Allan \& Alfredo Artiles (Eds.): The Routledge Yearbook of Education 2017, Assessment Inequalities, p. 68-88. London: Routledge.

Bachman. J. H., Votruba-Drzal, E., El Nokali, E. N., \& Castle Heatly, M. (2015). Opportunities for Learning Math in Elementary School: Implications for SES Disparities in Procedural and Conceptual Math Skills. American Educational Research Journal, 52(5), 894-923.

Bishop, A., Tan, H., \& Barkatsas, T. N. (2015) (Eds.), Diversity in Mathematics Education - Towards Inclusive Practices (pp. 239-253). Cham: Springer publishing.

Blömeke, S., Suhl, U., \& Döhrmann, M. (2013). Assessing strengths and weaknesses of teacher knowledge in Asia, Eastern Europe, and Western countries: Differential item functioning in TEDSM. In International Journal Of Science And Mathematics Education, 11(4), 795-817.

Blömeke, S., Schmidt, W., \& Hsieh, F., (2013). 2013 International Journal for Science and Mathematics Education Special Issue "International Perspectives on Mathematics and Science Teacher Education for the Future". International Journal of Science and Mathematics Education, 10(4), 997-999.

Bottge, B. A., Rueda, E., Serlin, R. C., Hung, Y.-H. \& Kwon, J. M. (2007). Shrinking Achievement Differences with Anchored Math Problems: Challenges and Possibilities. Journal of Special Education, 41(1), 31-49.

Dreher, K. (2012). Tests, testing times and literacy teaching. Australian Journal of Language and Literacy, 35(3), 334-352.

Erdogan, Niyazi, \& Stuessy, Carol. (2016). Examining the Role of Inclusive STEM Schools in the College and Career Readiness of Students in the United States: A Multi-Group Analysis on the Outcome of Student Achievement. Educational Sciences: Theory and Practice, 15(6), 1517-1529.

Feucht, F. C., \& Bendixen, L. D. (2010) Exploring Similarities and Differences in Personal Epistemologies of U.S. and German Elementary School Teachers, Cognition and Instruction, 28(1), 39-69.

Gal, H. \& Linchevski, L. (2010). To See or Not To See: Analyzing Difficulties in Geometry from the Perspective of Visual Perception. Educational Studies in Mathematics, 74(2), 163-183.

Grek, S. (2009) Governing by numbers: the PISA 'effect' in Europe, Journal of Education Policy, 24:1, 23-37, DOI: 10.1080/02680930802412669 
Bagger, A. \& Roos, H. (in press). The shared duty of special educational support in mathematics: borders and spaces in degree ordinances for pre-service teachers. In N. Radakovic \& L Jao (Eds.), Borders in Mathematics Pre-Service Teacher Education. Springer. Authors copy.

Griffin, C. D. N., Pape, S., Algina, J., Bae, J., Prosser, S., \& League, B. M. (2018). Prime Online: Exploring Teacher Professional Development for Creating Inclusive Elementary Mathematics Classrooms. Teacher Education and Special Education, 41(2), 121-139.

Göransson, K., Lindqvist, G., Klang, N., Magnusson, G., \& Nilholm, C (2015). Speciella yrken? En studie om specialpedagogers och speciallärares yrkesroll. Specialpedagogisk tidskrift - att undervisa, (3), 15-17.

Göransson, K., Lindqvist, G., \& Nilholm, C. (2015). Voices of Special Educators in Sweden: A TotalPopulation Study. Educational Research, 57(3), 287-304.

Göransson, K., Lindqvist, G., Möllås, G., Almqvist, L., \& Nilholm, C. (2017). Ideas about Occupational Roles and Inclusive Practices among Special Needs Educators and Support Teachers in Sweden. Educational Review, 69(4), 490-505.

Hinton, V., Flores, M., Burton, M., \& Curtis, R. (2015). An Investigation into Pre-Service Special Education Teachers' Mathematical Skills, Self-Efficacy, and Teaching Methodology. Issues in the Undergraduate Mathematics Preparation of School Teachers, 1, 1-13.

Heyd-Metzuyanim, E. (2013). The Co-Construction of Learning Difficulties in Mathematics-Teacher-Student Interactions and Their Role in the Development of a Disabled Mathematical Identity. Educational Studies in Mathematics, 83(3), 341368.

Holgersson, I., \& Wästerlid, C. (2018). Specialisering barns och elevers matematikutveckling. In B. Bruce (ed.), Att vara speciallärare: Språk-, skriv- och läsutveckling respektive matematikutveckling. (pp. 41-56). Malmö: Gleerups.

Isaksson, C., \& Larsson. A. (2017). Jurisdiction in school social workers' and teachers' work for pupils' well-being. 8(3), 246-261.

Kim. J.H., (2017) The Travelling of PISA: Fabricating the Korean Global Citizen and the Reason of Reforms. In: Thomas A. Popkewitz, Jennifer Diaz, \& Christopher Kirchgasler. (2017). A Political Sociology of Educational Knowledge: Studies of Exclusions and Difference. Taylor and Francis. (pp. 53-68).

Lester, F. K. (2007). Culture, race, power, and mathematics education. In F. K. Lester (Ed.), Second handbook of research on mathematics teaching and learning: A project of the National Council of Teachers of Mathematics, vol. 2. (pp. 405-433). Charlotte, NC: Information Age.

Lewis, K. E., \& Fisher, M. B. (2016). Taking stock of 40 years of research on mathematical learning disability: Methodological issues and future directions. Journal for Research in Mathematics Education, 47(4), 338-371. 
Bagger, A. \& Roos, H. (in press). The shared duty of special educational support in mathematics: borders and spaces in degree ordinances for pre-service teachers. In N. Radakovic \& L Jao (Eds.), Borders in Mathematics Pre-Service Teacher Education. Springer. Authors copy.

Lincove, J., Osborne, C., Mills, N., \& Bellows, L. (2015). Teacher Preparation for Profit or Prestige: Analysis of a Diverse Market for Teacher Preparation. Journal of Teacher Education, 66(5), 415434.

Luke, A. (2011). Generalizing across borders. Educational Researcher, 40(8), 367-377.

Martens, K., Knodel, P., \& Windzio, M. (2014). Outcomes and actors' reactions on internationalization in education policy: A theoretical approach. In K. Martens, P. Knodel, \& M. Windzio (Eds.), Internationalization of education policy: A new constellation of statehood in education? (pp. 1-34). Basingstoke, UK: Palgrave Macmillan.

Méndez, L., Lacasa, P. \& Matusov, E. (2008). Transcending the Zone of Learning Disability: Learning in Contexts for Everyday Life. European Journal of Special Needs Education, 23(1), 6373.

Moscardini, L. (2010). "I Like It Instead of Maths": How Pupils with Moderate Learning Difficulties in Scottish Primary Special Schools Intuitively Solved Mathematical Word Problems. British Journal of Special Education, 37(3), 130-138.

Moscardini, Lio. (2015). Primary Special School Teachers' Knowledge and Beliefs about Supporting Learning in Numeracy. Journal of Research in Special Educational Needs, 15(1), 37-47.

Moss, P. A., Pullin, D. C., Gee, J. P., Haertel, E. H., \& Young, L. J. (2008). Assessment, equity, and opportunity to learn. Cambridge University Press.

OECD (2017). PISA 2015 Assessment and Analytical Framework: Science, Reading, Mathematic, Financial Literacy and Collaborative Problem Solving. Ed. by OECD Publishing. Revised edition. Paris. url: http://dx.doi.org/10.1787/9789264281820-en.

Pettersson, D. (2008). Internationell kunskapsbedömning som inslag i nationell styrning av skolan (Doctoral thesis). Uppsala University, Uppsala, Sweden.

Piasta, S. B., Logan, J. A. R., Pelatti., C. Yeager., Capps, J. L., \& Petrill, S. A. (2015). Professional Development for Early Childhood Educators: Efforts to Improve Math and Science Learning Opportunities in Early Childhood Classrooms. Journal of Educational Psychology, 107(2), 407-422.

Radford, J., Bosanquet, P., Webster, R., \& Blatchford, P. (2015). Scaffolding learning for independence: Clarifying teacher and teaching assistant roles for children with special educational needs. Learning and Instruction, 36, 1-10.

Roos, H. (2015). Inclusion in mathematics in primary school: What can it be? (Licentiate thesis). Växjö: Linnaeus University. 
Bagger, A. \& Roos, H. (in press). The shared duty of special educational support in mathematics: borders and spaces in degree ordinances for pre-service teachers. In N. Radakovic \& L Jao (Eds.), Borders in Mathematics Pre-Service Teacher Education. Springer. Authors copy.

Roos, H., \& Gadler, U. (2018). Kompetensens betydelse i det didaktiska mötet - en modell för analys av möjligheter att erbjuda varje elev likvärdig utbildning enligt skolans uppdrag. Pedagogisk forskning i Sverige, 23(3-4), 290-307.

Rönnberg, L. (2011). Exploring the intersection of marketisation and central state control through Swedish national school inspection. Education Inquiry, 2(4), 695-713.

Schleicher, A. (Ed.) (2012). Preparing teachers and developing school leaders for the 21st century: Lessons from around the world. Paris: OECD Publishing. Retrieved from https://www.oecd.org/site/eduistp2012/49850576.pdf

Secher Schmidt, M. C. (2016). Dyscalculia $\neq$ maths difficulties: An analysis of conflicting positions at a time that calls for inclusive practices. European Journal of Special Needs Education, 31(3), 407-421.

SFS 1993:100. Högskoleförordningen. [Higher Education Ordinance]. Ministry of Education and Research, Sweden.

SFS (2010:800). Skollag. [Education Act]. Department of Education, Sweden.

Shade, A. R., \& Stewart, R. (2001). General Education and Special Education Preservice Teachers' Attitudes Toward Inclusion, Preventing School Failure: Alternative Education for Children and Youth, 46(1), 37-41, DOI: 10.1080/10459880109603342

Sherer, P., Beswick, K., DeBlois, L., Healey, L., \& Opitz, E.M. (2016). Assistance of students with mathematical learning difficulties: how can research support practice? ZDM: the international journal on mathematics education, 48(5), 639-649.

Stobart, G. (2009). Determining validity in national curriculum assessments. Educational Research, 51:2, 161-179.

Sundqvist, C., \& Ström, K. (2015). Special Education Teachers as Consultants: Perspectives of Finnish Teachers. Journal of Educational and Psychological Consultation, 25(4), 1-26.

United Nations (1989) Convention on the Rights of the Child. Retrieved 18th May 2019 from https://unicef.se/barnkonventionen/las-texten\#full

Van Ingen, S., Eskelson, S. L., \& Allsopp, D. (2016). Evidence of the Need to Prepare Prospective Teachers to Engage in Mathematics Consultations. Mathematics Teacher Education and Development, 18(2), 73-91.

Wang, T. Y., \& Tang, S. J. (2013). Profiles of Opportunities to Learn for TEDS-M Future Secondary Mathematics Teachers. International Journal of Science and Mathematics Education, 11(4), 847877. 
Bagger, A. \& Roos, H. (in press). The shared duty of special educational support in mathematics: borders and spaces in degree ordinances for pre-service teachers. In N. Radakovic \& L Jao (Eds.), Borders in Mathematics Pre-Service Teacher Education. Springer. Authors copy.

Weiss, M. P., Pellegrino, A., Regan, K., Mann, L. (2015). Beyond the blind date collaborative course development and co-teaching by teacher educators. Teacher Education and Special Education, $38(2), 88-104$.

Wenger, E. (1998). Communities of practice. Learning, Meaning and Identity. Cambridge: Cambridge University Press.

Wrigley, T. (2010). The testing regime of childhood: up against the wall. In D. Kassem, L. Murphy, \& E. Taylor (Eds.), Key issues in childhood and youth studies: Critical issues (pp. 136-148). New York: Routledge. 